\title{
CONODONTS OF THE POLYGNATHUS POLLOCKI DRUCE GROUP (UPPER DEVONIAN, LOWER FRASNIAN) FROM THE EAST EUROPEAN PLATFORM
}

\author{
Andrey V. ZHURAVLEV
}

\begin{abstract}
All-Russian Geological Research Institute (VSEGEI), 74 Sredniy Pr., St Petersburg, Russia; stratigr@mail.wplus.net
\end{abstract}

Received 19 March 1998, in revised form 3 August 1998

\begin{abstract}
Conodonts of the Polygnathus pollocki Druce group are described from the Lower Frasnian shallow-water shelf deposits of the Main Devonian Field, East European Platform (Russia). One new species ( $P$. drucei sp. nov.) is erected and two new species are described in open nomenclature (Polygnathus sp. nov. A and Polygnathus sp. nov. B). Two morphotypes of P. pollocki are recognized. Preliminary phylogenetic and ecological reconstructions for the group are considered.
\end{abstract}

Key words: Upper Devonian, Frasnian, conodonts, new species.

\section{INTRODUCTION}

The Early Frasnian polygnathids, known as taxa characterizing mainly the shallow-water facies, are represented by morphologically diverse forms. Many polygnathids of this age possess an elongate, lanceolate platform ornamented, as a rule, with weak transverse ridges. They are considered to belong to the Polygnathus decorosus stock (Ziegler, 1965; Huddle, 1970). Some of these species (with a strongly elongated platform) are regarded herein as the $P$. pollocki Druce group, which represents a lineage characterized by narrowing of the platform and development of longitudinal ornamentation. According to Druce (1976), this lineage probably evolved from the $P$. decorosus stock and displays symmetry class II sensu Lane (1968), in contrast to the $P$. webbi stock which is characterized by symmetry class III.

Conodonts of the $P$. pollocki lineage have been studied by the author from the Lower Frasnian shallow-water carbonate-siliciclastic sections of the Main Devonian Field (East European Platform, Russia). Most of the sections are located 


\begin{tabular}{|c|c|c|c|c|}
\hline \multirow[b]{2}{*}{ 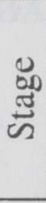 } & \multirow[b]{2}{*}{ 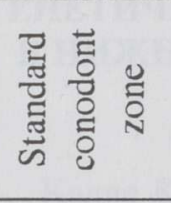 } & \multicolumn{3}{|c|}{ Main Devonian Field } \\
\hline & & $\begin{array}{l}\text { Regional } \\
\text { substage }\end{array}$ & $\begin{array}{l}\text { Formation } \\
\text { (Beds) }\end{array}$ & $\begin{array}{c}\text { Local conodont zone } \\
\text { (Zhuravlev et al., } \\
1997)\end{array}$ \\
\hline \multirow{3}{*}{ 톨 } & $\begin{array}{c}\text { U. hassi - } \\
\text { jamieae }\end{array}$ & $\begin{array}{l}\text { Rechitsian } \\
\text { (lower part) }\end{array}$ & $\begin{array}{c}\text { Snezha } \\
\text { (lower part) }\end{array}$ & $?$ \\
\hline & \multirow[t]{2}{*}{$\begin{array}{c}\text { punctata - } \\
\text { L. hassi }\end{array}$} & \multirow{2}{*}{$\begin{array}{l}\text { Semilukian } \\
\text { (upper part) }\end{array}$} & Buregi & Polygnathus efimovae \\
\hline & & & Ilmen & Polygnathus pollocki \\
\hline
\end{tabular}

Fig. 1. Stratigraphical chart.

in the Lake Ilmen region (Novgorod district) and provide abundant conodont associations commonly dominated by species of Polygnathus s. 1. (for details see Zhuravlev et al., 1997). Conodont studies in this region were accompanied by facial, palaeoecological, and palaeotemperature investigations. The $\mathrm{Ca} / \mathrm{Mg}$ ratios, measured by Dr L. Dorofeeva (VSEGEI, St Petersburg, Russia) in brachiopod shells (Cyrtospirifer and Atrypa), indicate the palaeotemperatures of about $19-20^{\circ} \mathrm{C}$.

In the present paper the correlation of the regional stratons (such as the Semilukian Substage, Ilmen, Buregi, and Snezha formations) with the standard conodont zonation, suggested by Ovnatanova (1974), Aristov (1988), Ovnatanova \& Kuz'min (1991), Ovnatanova \& Kononova (1996), and Zhuravlev et al. (1997), is used with minor revision (Fig. 1). The sample numbers mentioned correspond to those in Zhuravlev et al. (1997).

\section{SYSTEMATIC PALAEONTOLOGY}

The following five species are regarded as belonging to the Polygnathus pollocki group: P. pollocki Druce (two morphotypes are recognized); P. efimovae Kononova, Alekseev, Barskov et Reimers, P. drucei sp. nov., Polygnathus sp. nov. A, and Polygnathus sp. nov. B (see Pls. I, II).

The species differ in proportions and ornamentation of the platform of the $\mathrm{Pa}$ element. The composition of the apparatus is difficult to reconstruct because of high taxonomic diversity (up to 20 formal species) of conodont associations studied.

The measurements of conodont elements mentioned in text are shown in Fig. 2. The collection studied is deposited in the F. N. Tschernyshev Central Geological Museum (CNIGR Museum), St Petersburg, Russia; collection Nos. 13019 and 13003 (one specimen). Holotype of $P$. pollocki Druce (PI. II, fig. 4) is reillustrated from Druce, 1976 (pl. 62, fig. 3b). 


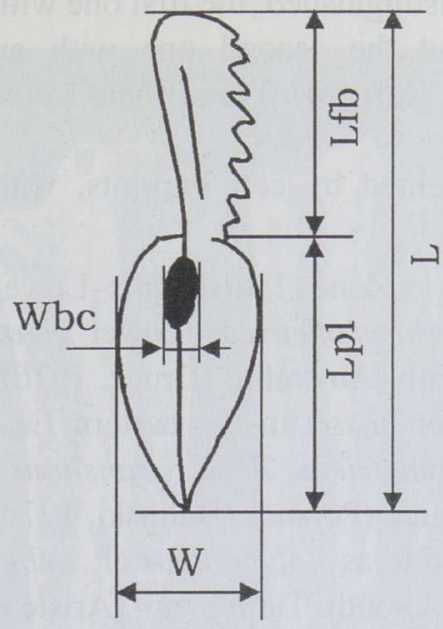

Fig. 2. Measurements of the $\mathrm{Pa}$ element: $\mathrm{L}$, total length of the element; Lfb, length of the free blade; $\mathrm{Lpl}$, length of the platform; W, width of the platform; Wbc, width of basal cavity flanks.

Genus Polygnathus Hinde, 1879

Polygnathus pollocki Druce, 1976

Plate I, figures $1-4,6,7$

1968 Polygnathus n. sp. A; Pollock, p. 436, pl. 62, figs. 32, 33, 38.

1974 Polygnathus sp. B; Uyeno, pl. 5, fig. 8.

1976 Polygnathus pollocki Druce, p. 198, pl. 79, figs. 2-4; text-fig. 24.

1979 Polygnathus pollocki Druce; Balinski, pp. 80-81, pl. 23, figs. 7, 8.

1985 Polygnathus pollocki Druce; Ovnatanova \& Aristov, pl. 5, fig. 12.

1992 Polygnathus pollocki Druce; Racki, fig. 32D,F.

1993 ?Polygnathus pollocki Druce; Racki \& Bultynck, pl. 4, figs. 4, 5 (non fig. 3, = Polygnathus decorosus Stauffer).

1995 Polygnathus cf. webbi Stauffer; Shen Jian-Wei, pl. 2, figs. 15, 16.

1996 Polygnathus pollocki Druce; Kononova et al., pl. 12, figs. 11, 12.

1997 Polygnathus pollocki Druce; Zhuravlev et al., pl. I, figs. 5, 6.

Holotype. Sample BG 19543, Section 9, McPhee Knoll, Gogo Formation; CPC 12735 .

Original diagnosis. A polygnathid with a very elongate and narrow platform (Druce, 1976).

Revised diagnosis. Polygnathid $\mathrm{Pa}$ element with elongate platform $(\mathrm{Lpl} / \mathrm{W}=3-5)$ having lateral margins bent inwards (omega-like transverse section of platform), and slightly undulated carina.

Material. More than $100 \mathrm{~Pa}$ elements of various preservation. 
Remarks. Two morphotypes of $P$. pollock $i$ can be distinguished: the first one with a platform ornamented by transverse ridges, and the second one with an unornamented platform (see Pl. I, figs. 1-4, 6, 7; Pl. II, fig. 4). Transitional forms also occur.

Micro-ornamentation of the platform is represented by cell imprints, with average size varying from 6.4 to $7.8 \mu \mathrm{m}$.

Occurrence. Upper Devonian, Frasnian, asymmetricus Zone (? falsiovalis-Lower hassi) in Alberta (Canada) (Pollock, 1968); Middle asymmetricus-Lower gigas zones (punctata-Lower rhenana) in the Canning Basin (Australia) (Druce, 1976); Middle-Upper asymmetricus Zone (punctata-Lower hassi) in the eastern East European Platform (Russia); Lower-Middle asymmetricus Zone (transitanspunctata) in the Holy Cross Mountains and Debnik area (Poland) (Balinski, 1979; Racki, 1992); falsiovalis Zone, South China (referred to as Polygnathus cf. webbi by Shen, 1995); asymmetricus-gigas zones in the South Tien Shan (Aristov, 1994).

\section{Polygnathus pollocki Morphotype 1 \\ Plate I, figures $1,2,6,7$}

1974 Polygnathus sp. B; Uyeno, pl. 5, fig. 8.

1976 Polygnathus pollocki Druce, p. 198, pl. 79, figs. 2-4; text-fig. 24.

1979 Polygnathus pollocki Druce; Balinski, pp. 80-81, pl. 23, figs. 7, 8.

1985 Polygnathus pollocki Druce; Ovnatanova \& Aristov, pl. 5, fig. 12.

1993 ?Polygnathus pollocki Druce; Racki \& Bultynck, pl. 4, figs. 4, 5 (non fig. 3).

Diagnosis. Polygnathus pollocki; platform margins of Pa element are ornamented by weak transverse ridges.

Material. 17 well-preserved $\mathrm{Pa}$ elements.

\section{Explanation of Plate I}

Figs. 1-4, 6, 7. Polygnathus pollocki Druce, 1976. 1, Morphotype 1, 10/13019, ×85, 5101/6; 2, Morphotype 1, 4/13019, ×68,5101/4; 3, Morphotype 2, 13/13019, ×57, 5101/3; 4, Morphotype 2, $8 / 13019, \times 52,5101 / 6 ; 6$, Morphotype 1 , micro-ornamentation in the left posterior part of the platform, 5/13019, $\times 570,5101 / 7 ; 7$, Morphotype 1, 5/13019, $\times 57,5101 / 7$.

Fig. 5. Polygnathus sp. nov. A, 12/13019, × 48, 5102/1.

Fig. 8. Polygnathus sp. nov. B, 7/13019, × 48, 5119/4.

Figs. 9-11. Polygnathus efimovae Kononova, Alekseev, Barskov et Reimers, 1996. 9, basal cavity, 9/13019, × 230, 5103/10; 10, lower view, 9/13019, ×58,5103/10; 11,6/13019, ×62, 5103/10. 

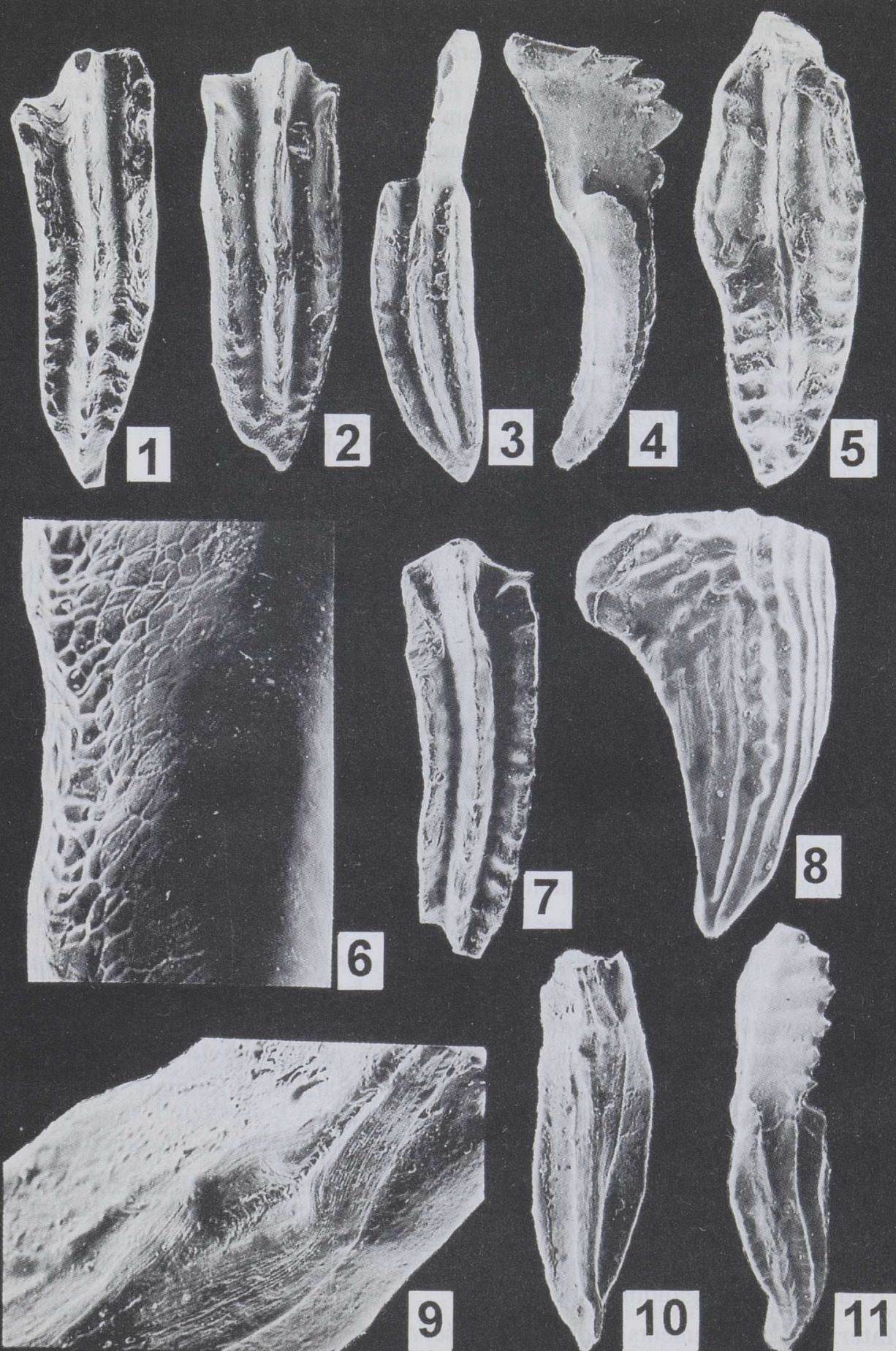
Remarks. The holotype of Polygnathus pollocki Druce (1976, pl. 79, fig. 4) belongs to this morphotype, but the original description (Druce, 1976, p. 198) is closer to Morphotype 2 which has smooth platform margins (see below). Platform ornamentation varies from weak to moderate, transitional forms from Morphotype 1 (M1) to Morphotype 2 (M2) exist.

Polygnathus pollocki M1 differs from the Middle Devonian P. timorensis Klapper, Philip et Jackson in having inwardly bent platform margins and shorter free blade. Otherwise these species are highly homeomorphic.

\section{Polygnathus pollocki Morphotype 2 \\ Plate I, figure 3}

1992 Polygnathus pollocki Druce; Racki, fig. 32D,F.

1996 Polygnathus pollocki Druce; Kononova et al., pl. 12, fig. 12.

1997 Polygnathus pollocki Druce; Zhuravlev et al., pl. I, fig. 6.

Diagnosis. Polygnathus pollocki; Pa element with non-ornamented platform margins and less elongated platform (average Lpl/W $=3$ ) than in Morphotype 1. Only some specimens bear transverse ridges, or elongated nodes, in the posteriormost part of the platform.

Material. 21 well-preserved $\mathrm{Pa}$ elements.

Remarks. Polygnathus pollocki M2 is a probable ancestor of $P$. drucei, which evolved by developing the lateral rims in the platform margins. This morphotype is similar to $P$. decorosus Stauffer, but differs in having a platform with inwardly bent margins (omega-like transverse section of the platform).

Polygnathus efimovae Kononova, Alekseev, Barskov et Reimers, 1996

Plate I, figures 9-11; Plate II, figures 2, 10

1985 Polygnathus ordinatus Bryant; Ovnatanova \& Aristov, pl. 5, figs. 10, 11.

1988 Polygnathus ex. gr. ordinatus Bryant; Aristov, pl. 2, figs. 1-3, 5.

1996 Polygnathus efimovae Kononova et al., p. 96, pl. 12, figs. 14-17.

1997 Polygnathus efimovae Kononova, Alekseev, Barskov et Reimers; Zhuravlev et al., pl. I, figs. 11,13 .

Holotype. Sample 128, borehole 1 Gavrilov-Yam, Semilukian Substage; Palaeontological Department, Moscow State University 272/26.

Diagnosis. Polygnathid $\mathrm{Pa}$ element with arched elongate lenticular platform bearing 2-6 subparallel longitudinal ridges.

Material. $82 \mathrm{~Pa}$ elements of different preservation. 
Description. Polygnathid $\mathrm{Pa}$ element characterized by elongate lenticular platform, arched and slightly bowed laterally. The platform bears 2 to 6 subparallel longitudinal smooth or slightly nodose ridges. Carina smooth or nodose and S-like bent. Free blade short $(\mathrm{Lfb} / \mathrm{L}=0.3-0.5)$ in adult specimens. Average size of the cell imprints on the platform varies from 4.6 to $7.3 \mu \mathrm{m}$. Keel sharp and distinct. A small basal cavity is located in the anterior third of the platform. It has poorly developed flanks in adult specimens, but is large and flanked in immature specimens.

Remarks. This species differs from Polygnathus ordinatus Bryant in having many longitudinal ridges which are parallel to the carina, and in having S-shaped undulation of the carina. From morphologically close $P$. rudkinensis Ovnatanova et Kononova $P$. efimovae differs in smoother longitudinal ridges and in the general form of the platform.

Occurrence. Upper Devonian, Frasnian; Buregi and lowermost Snezha formations (upper part of the Semilukian Substage), East European Platform.

\section{Polygnathus drucei sp. nov.}

Plate II, figures 1, 3, 5-9

1996 Polygnathus pollocki Kononova et al., pl. 12, fig. 13.

Holotype. Sample 5101/7, CNIGR Museum, St Petersburg, No. 1/13019.

Type locality. Lake Ilmen region, section 5101 (see Zhuravlev et al., 1997 for the description and location of the section).

Type horizon. Upper Devonian, Lower Frasnian, Semilukian, Ilmen Beds (Formation).

Derivation of name. In honour of Dr E. C. Druce.

Diagnosis. Polygnathid $\mathrm{Pa}$ element with lanceolate elongate platform bearing (on each side of platform) one or two longitudinal ridges separated from platform margins by rims.

Material. 19 well-preserved $\mathrm{Pa}$ elements and 27 strongly broken elements.

Description. Polygnathid $\mathrm{Pa}$ element with a lanceolate elongate platform, which is arched and slightly bowed laterally. Platform bears, mainly in the posterior part, one or two narrow lateral rims, nodose in some specimens. The rims separate longitudinal ridges (one or two) from platform margins. Adcarinal troughs are deep and narrow. Average size of the cell imprints on the platform margins varies from 6.5 to $8.3 \mu \mathrm{m}$. Keel sharp and distinct. Basal cavity moderate, with poorly developed flanks. Width of basal cavity flanks decreases during ontogeny due to growing over. 


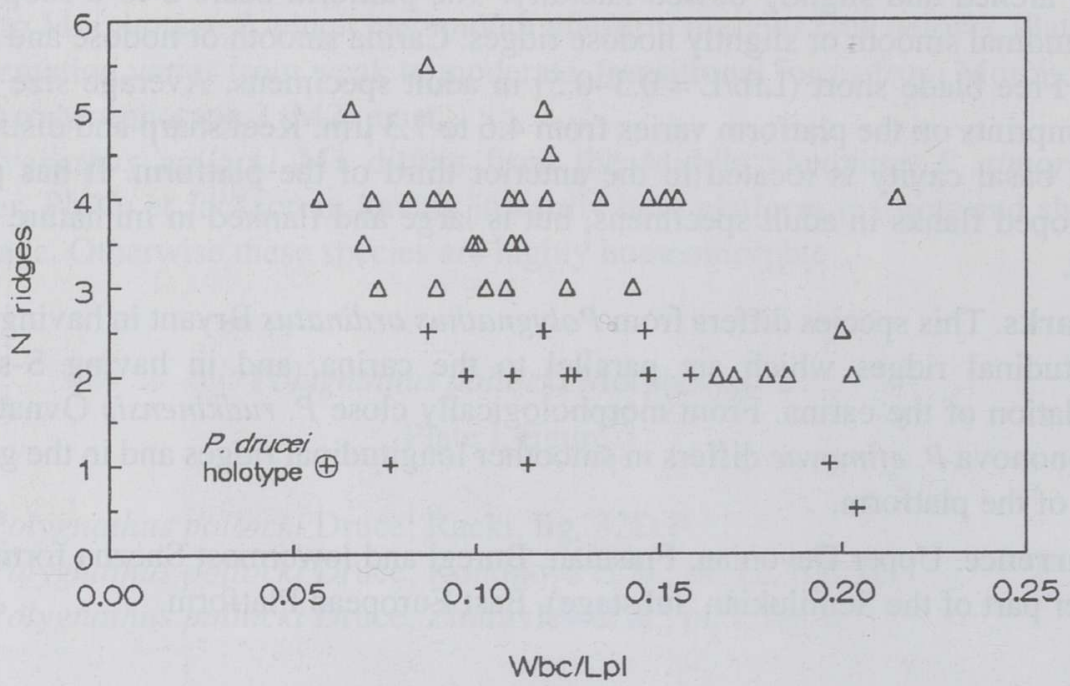

Fig. 3. Scattered plot diagram showing biometric differences between Polygnathus efimovae Kononova, Alekseev, Barskov et Reimers and $P$. drucei sp. nov. $\mathrm{N}$ ridges - number of longitudinal ridges on the platform.

Remarks. This species is close to the immature forms of $P$. efimovae, but differs in having smaller flanks of the basal cavity and poorly developed longitudinal ridges (only two ridges even in adult specimens). Certain correlation between the number of longitudinal ridges and relative width of the basal cavity flanks forms the biometrical diagnostic feature (see Fig. 3). Also, the basal cavity is located closer to the midpoint of the platform than in P. efimovae.

Morphologically similar $P$. lingulatus Ovnatanova differs from the new species in having rather nodose longitudinal ornamentation, a nodose carina, as well as a rounded posterior tip of the platform.

\section{Explanation of Plate II}

Figs. 1, 3, 5-9. Polygnathus drucei sp. nov. 1, 11/13019, ×85, 5101/6; 3, 2/13019, × 60, 5101/5C; 5 , micro-ornamentation of holotype, $1 / 13019, \times 570,5101 / 7 ; 6$, upper view of holotype, 1/13019, $\times 48,5101 / 7 ; 7$, oblique lateral view of holotype, $1 / 13019, \times 48,5101 / 7 ; 8$, lateral view of holotype, $1 / 13019, \times 48,5101 / 7 ; 9$, micro-ornamentation, 11/13019, $\times 620,5101 / 6$.

Figs. 2, 10. Polygnathus efimovae Kononova, Alekseev, Barskov et Reimers, 1996. 2, 3/13019, × 90, $5103 / 10 ; 10,13 / 13003, \times 37,5103 / 9$.

Fig. 4. Polygnathus pollocki Druce. Holotype, $\times$ 58, re-illustration from Druce, 1976 (pl. 62, fig. 3b). 

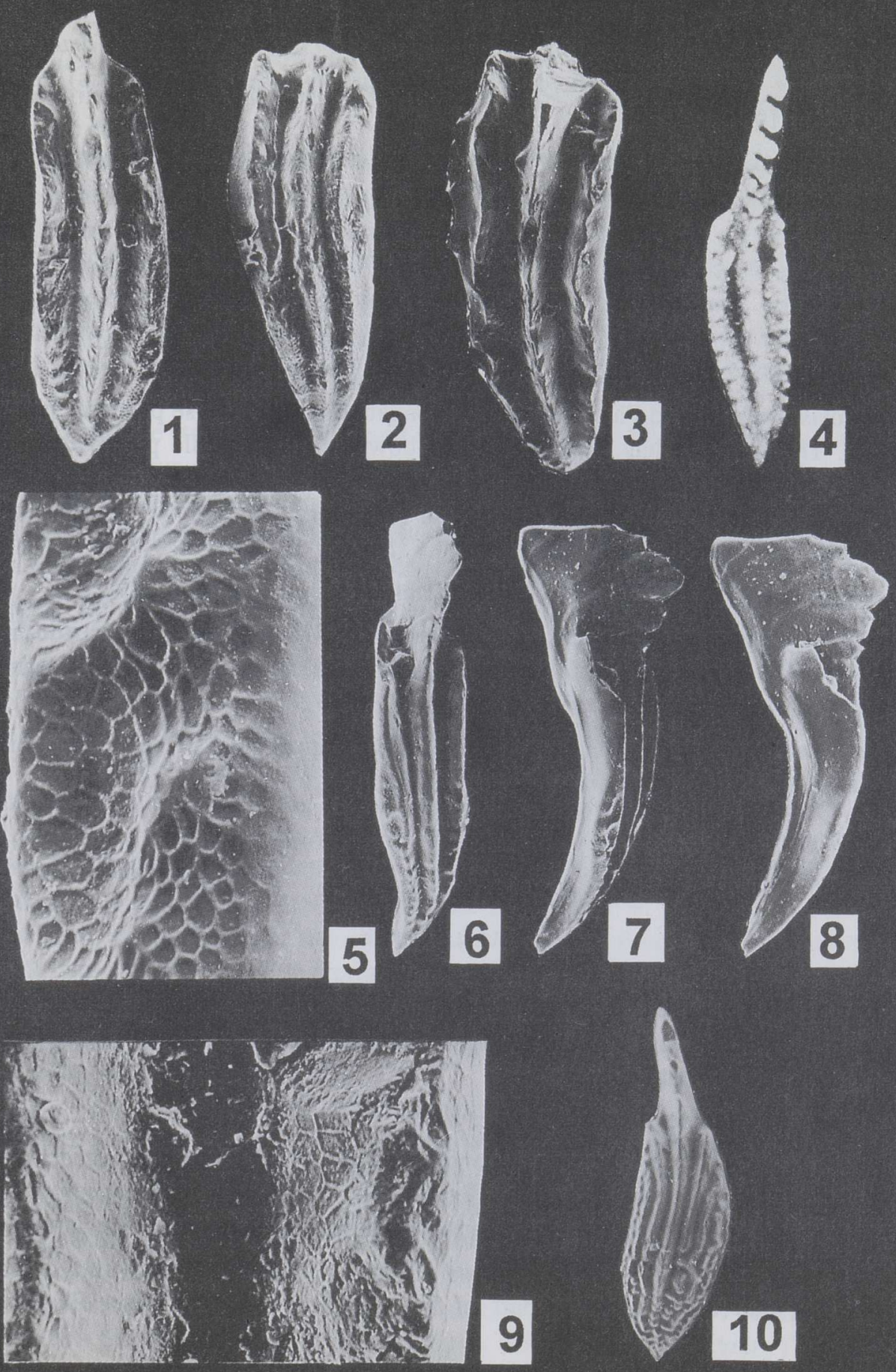
Polygnathus drucei is distinguishable from $P$. pollocki M2 in having a lateral rim (or rims), relatively wider platform (average $\mathrm{Lpl} / \mathrm{W}=3$ ), and different position of the basal cavity.

The proposed phyletic succession from $P$. pollocki M2 through $P$. drucei to $P$. efimovae demonstrates the heterochrony process (hypermorphosis) sensu McKinney (1986).

Occurrence. Upper Devonian, Lower Frasnian, Semilukian Substage, Ilmen and Buregi formations, East European Platform.

\section{Polygnathus sp. nov. A \\ Plate I, figure 5}

Diagnosis. Polygnathid $\mathrm{Pa}$ element with elongate platform whose posterior part is ribbed. The platform has S-shaped lateral bowing in its middle part. Adcarinal troughs are deep anteriorly and become shallower in the posterior part of the platform. Platform margins are elevated in the anterior part of the platform and form here a rostrum-like structure.

Material. 3 specimens from different samples.

Remarks. This species differs from $P$. pollocki M1 in having a rostrum-like anterior elevation of platform margins and in the absence of deep adcarinal troughs in the posterior part of the platform.

Occurrence. Upper Devonian, Lower Frasnian, upper part of the Semilukian Substage, Ilmen Formation, East European Platform.

\section{Polygnathus sp. nov. B \\ Plate I, figure 8}

Diagnosis. Polygnathid $\mathrm{Pa}$ element with elongate subtriangular platform bearing a number of subparallel longitudinal ridges and possessing a nodose ornamentation on the outer antero-lateral lobe.

Material. $4 \mathrm{~Pa}$ elements of poor preservation.

Remarks. These forms seem to belong to a new species, but are not aberrant specimens of $P$. efimovae. However, due to the small number of specimens (only 4) and their poor preservation, these forms are described in open nomenclature.

Occurrence. Upper Devonian, Lower Frasnian, upper part of the Buregi Formation and the lowermost part of the Snezha Formation, East European Platform. 


\section{REMARKS AND CONCLUSIONS}

Conodont zonation for the shallow-water Polygnathus biofacies of the Frasnian is not yet developed. Thus the precise correlation of evolutionary events in the $P$. pollocki lineage is difficult. The preliminary phylogenetic reconstruction is based mainly on morphological similarities of the species, without precise stratigraphic control.

Immature specimens of all species of the $P$. pollocki group are similar and resemble $P$. pollocki M2. The last one is considered to be the probable ancestor of the $P$. pollocki lineage. The second member of the lineage, $P$. pollocki M1, gave rise to Polygnathus sp. nov. A. Polygnathus drucei evolved from P. pollocki M2. Thus the morphotypes of $P$. pollocki probably represent an early morphological divergence in this lineage. Then (in the late Semilukian) $P$. efimovae arose from $P$. drucei, and some advanced forms of $P$. efimovae gave rise to Polygnathus $\mathrm{sp}$. nov. B.

The lineage studied demonstrates strong homeomorphy (in general sense) with the Polygnathus latifossatus-Schmidtognathus wittekindti lineage (Kononova et al., 1996). The P. pollocki lineage shows also some common features with a number of other polygnathid lineages, namely, developing from the unornamented (or poorly ornamented) platform, through the platform ornamented by transverse ribs, to the platform ornamented by longitudinal ridges. This morphological trend can be observed in the Upper Devonian-Lower Carboniferous genus $\mathrm{NeO}$ polygnathus ( $N$. communis (Branson et Mehl)-N. dentatus (Druce) $-N$. talassicus (Nigmadzhanov)), Lower Carboniferous genus Siphonodella (S. sulcata HuddleS. sandbergi Klapper), and in some other conodont genera.

Palaeogeographically, the P. pollocki group inhabited the tropic and southern subtropic realms, mainly the Prototethys shelves. The oldest representatives of the $P$. pollocki group are known from South China ( $P$. pollocki in the falsiovalis conodont Zone, figured by Shen as $P$. cf. webbi; Shen, 1995, pl. 2, figs. 15, 16) and the youngest ones from the South Tien Shan ( $P$. pollocki in the gigas (rhenana) conodont Zone; reported by Aristov, 1994). Probably, the South China shelf was the centre of the origination of the P. pollocki group. The highest diversity of this group in the East European Platform has been detected in the Semilukian Substage (punctata-Lower hassi conodont zones). All the species of the group discussed occur there.

The conodonts of the $P$. pollocki group are abundant in the shallow-water facies and correspond to the Polygnathus biofacies sensu Klapper \& Lane (1985). They were not strongly dependent on the palaeotemperature and inhabited both, the relatively cool water $\left(19-20^{\circ} \mathrm{C}\right.$ in the East European Platform basin) and warm water (at least $24^{\circ} \mathrm{C}$ in the Western Australian basin according to Compston, 1960) environments. The species of the P. pollocki group are most common in shallow-water clastic carbonates, in association with P. lanei Kuzmin, $P$. webbi Stauffer, P. ljaschenkoi Kuzmin, and Mehlina gradata Youngquist. 
Polygnathus pollocki M2 is closely associated with Icriodus subterminus Youngquist as well. Thus the morphotypes of $P$. pollocki demonstrate not only morphological but also some ecological differentiation.

\section{REFERENCES}

Aristov, V. A. 1988. Devonian Conodonts of Central Devonian Field (Russian Platform). Nauka, Moscow (in Russian).

Aristov, V. A. 1994. Devonian and Lower Carboniferous Conodonts of the Eurasia. Nauka, Moscow (in Russian).

Balinski, A. 1979. Brachiopods and conodonts from the Frasnian of the Debnik anticline, Southern Poland. Palaeontol. Polonica, 39, 3-95.

Compston, W. 1960. The carbon isotopic compositions of certain marine invertebrates and coals from the Australian Permian. Geochim. Cosmochim. Acta, 18, 1/2, 1-22.

Druce, E. C. 1976. Conodont biostratigraphy of the Upper Devonian Reef Complexes of the Canning Basin, Western Australia. Bur. Miner. Resour., Geol. Geophys. Bull., 158, 1-234.

Huddle, J. W. 1970. Revised descriptions of some Late Devonian polygnathid conodonts. J. Paleontol., 44, 6, 1029-1040.

Klapper, G. \& Lane, H. R. 1985. Upper Devonian (Frasnian) conodonts of the Polygnathus biofacies, N.W.T., Canada. J. Paleontol., 59, 4, 904-951.

Kononova, L. I., Alekseev, A. S., Barskov, I. S. \& Reimers, A. N. 1996. New species of Polygnathid conodonts from Frasnian of Moscow Syneclise. Paleontol. Zh., 3, 94-99 (in Russian).

Lane, H. R. 1968. Symmetry in conodont element-pairs. J. Paleontol., 42, 5, 1258-1263.

McKinney, M. L. 1986. Ecological causation of heterochrony: a test and implications for evolutionary theory. Paleobiology, 12, 3, 282-289.

Ovnatanova, N. S. 1974. Zonation of the Frasnian Stage of the Russian Platform based on conodonts. Izv. AN SSSR, Ser. Geol., 9, 133-140 (in Russian).

Ovnatanova, N. S. \& Aristov, V. A. 1985. Conodont complexes from the Polygnathus asymmetricus (Upper) and Palmatolepis gigas zones from central regions of the East European Platform. In Stratigraficheskie issledovaniya prirodnykh rezervuarov nefti $i$ gaza (Il'in, V. D. \& Lipatova, V. V., eds.), pp. 28-34. VNIGNI, Moscow (in Russian).

Ovnatanova, N. S. \& Kononova, L. I. 1996. Some new Frasnian species of Polygnathus genus (Conodonta) from the Central part of the Russian Platform. Paleontol. Zh., 1, 54-60 (in Russian).

Ovnatanova, N. S. \& Kuz'min, A. V. 1991. Conodonts of the type sections of Domanik Formation of South Timan. Izv. AN SSSR, Ser. Geol., 3, 37-49 (in Russian).

Pollock, C. A. 1968. Lower Upper Devonian conodonts from Alberta, Canada. J. Paleontol., 42, 415-443.

Racki, G. 1992. Evolution of the bank to reef complex in the Devonian of the Holy Cross Mountains. Acta Palaeontol. Polonica, 37, 2/4, 87-182.

Racki, G. \& Bultynck, P. 1993. Conodont biostratigraphy of the Middle to Upper Devonian boundary beds in the Kielce area of the Holy Cross Mts. Acta Geol. Polonica, 43, 1, 1-33.

Shen, J.-W. 1995. Middle-Upper Devonian conodont succession and sea-level change in Guilin. Acta Micropalaeontol. Sinica, 12, 3, 251-273.

Uyeno, T. T. 1974. Conodonts of the Waterways Formation (Upper Devonian) of northeastern and central Alberta. Geol. Surv. Canada Bull., 232, 1-93.

Zhuravlev, A., Evdokimova, I. \& Sokiran, E. 1997. New data on conodonts, brachiopods, and ostracodes from the stratotypes of the Ilmen and Buregi beds (Frasnian, Main Devonian Field). Proc. Estonian Acad. Sci. Geol., 46, 4, 169-186.

Ziegler, W. 1965. Eine Verfeinerung der Conodontengliederung an der Grenze Mittel-/Oberdevon. Fortschr. Geol. von Rheinland und Westfalen, 9, 647-676. 


\title{
POLYGNATHUS POLLOCKI DRUCE RÜHMA KONODONDID (ÜLEMDEVON, ALAM-FRASNES, IDA-EUROOPA PLATVORM)
}

\author{
Andrei V. ŽURAVLJOV
}

On kirjeldatud Ida-Euroopa platvormi Alam-Frasnes'i madalveelist päritolu settekivimitest leitud uusi konodondiliike Polygnathus drucei sp. nov., Polygnathus sp. nov. A ja Polygnathus sp. nov. B ning liigi $P$. pollocki Druce koosseisus kaht uut morfotüüpi. Kõik kirjeldatud konodondid kuuluvad $P$. pollocki rühma. Lühidalt on käsitletud ka selle rühma konodontide arengut ja suhet keskkonnaga.

\section{КОНОДОНТЫ ГРУППЫ POLYGNATHUS POLLOCKI DRUCE (ВЕРХНИЙ ДЕВОН, НИЖНИЙ ФРАН, ВОСТОЧНО-ЕВРОПЕЙСКАЯ ПЛАТФОРМА)}

Андрей В. ЖУРАВЛЕВ

Из нижнефранских мелководно-шельфовых отложений Главного девонского поля (Восточно-Европейская платформа, Россия) описаны конодонты группы Polygnathus pollocki Druce. Выделен новый вид Polygnathus drucei sp. nov. и описаны в открытой номенклатуре два новых вида (Polygnathus sp. nov. A, Polygnathus sp. nov. В). Для Polygnathus pollocki установлено два морфотипа. Кратко обсуждаются предполагаемые филогения и экология рассматриваемой группы полигнатид. 